\title{
$\checkmark$ Successful Thrombectomy for Case Endocarditis-Related Stroke in a Very Young Patient: Illustrative Case
}

Yusuke Ikeuchi, Noriaki Ashida, Masamitsu Nishihara, and Kohkichi Hosoda

Objective: Unlike in older adults, ischemic stroke in young patients occurs secondary to preexisting conditions. Infective endocarditis (IE) is among the most important causes of stroke in young adults and has a severe prognosis. There are few reports of mechanical thrombectomy (MT) for IE-induced large-vessel occlusion (LVO). This paper reports a case of acute IE-induced LVO in a young patient who was successfully treated with MT.

Case Presentation: An 18-year-old woman presented to our hospital with severe headache, high fever, and left fingertip pain. She was admitted to the Department of Neurology for conservative treatment of suspected meningitis. On day 2 of admission, she developed acute left hemiparesis, left hemispatial neglect, and dysarthria. MRA showed occlusion of the right M1 segment of the middle cerebral artery, and the patient immediately underwent MT. After a single pass, we achieved thrombolysis in cerebral infarction $2 \mathrm{~b}$. A white clot was diagnosed as a vegetation on pathological examination. As transesophageal echocardiography showed a vegetation on the mitral valve, the patient was diagnosed with IE and underwent cardiovascular surgery. The patient recovered well and underwent additional treatment and rehabilitation.

Conclusion: Although rare, IE-induced septic emboli may occur in young patients with LVO, necessitating MT and pathological diagnosis of the clot.

Keywords > infective endocarditis, mechanical thrombectomy, young stroke, endovascular therapy, infection

\section{Introduction}

Ischemic stroke in young adults is more likely to occur secondary to preexisting conditions such as congenital or acquired heart disease, coagulation abnormalities, vascular dissection, infective endocarditis (IE), vasculitis, trauma, and autoimmune diseases than in older adults, ${ }^{1)}$ necessitating careful diagnosis and prompt treatment. IE, an important cause of stroke in the young, has a severe

Division of Neurosurgery, Nishi-Kobe Medical Center, Kobe, Hyogo, Japan

Received: August 30, 2021; Accepted: November 8, 2021 Corresponding author: Yusuke Ikeuchi. Department of Neurosurgery, Nishi-Kobe Medical Center, 5-7-1, Kojidai, Nishi-ku, Kobe, Hyogo 651-2273, Japan

Email: ikesuke35@yahoo.co.jp

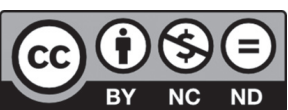

This work is licensed under a Creative Commons Attribution-NonCommercialNoDerivatives International License.

(C)2021 The Japanese Society for Neuroendovascular Therapy prognosis as less than one-third of patients remain alive and functionally independent. ${ }^{2)}$

IE-induced cerebral embolism is sometimes treated with thrombolysis and mechanical thrombectomy (MT). Since intravenous (IV) thrombolysis is not recommended because of the risk of hemorrhagic conversion due to vessel friability from septic emboli or mycotic aneurysms, ${ }^{3)}$ MT is the treatment of choice.

According to the modified Duke diagnostic criteria, confirmation of septicemia and vegetations on blood culture and echocardiography, respectively, is important for a definitive diagnosis of IE. ${ }^{4)}$ However, these tests cannot be conducted when urgent MT is required. In young patients with fever and large-vessel occlusion (LVO) with no other source of embolism, IE should be suspected before MT is performed, and if doubts exist, recombinant tissue plasminogen activator (rtPA) therapy should be avoided. ${ }^{3,5)}$

We report a case of acute IE-induced LVO in a young patient who was successfully treated with MT. Pathological examination of the thrombus enabled rapid diagnosis. 


\section{Case Presentation}

An 18-year-old woman with no relevant medical, family, or infectious disease contact history, lifestyle factors, or substance use presented with fever (body temperature: $39^{\circ} \mathrm{C}$ ) and headache. Laboratory examination revealed a high blood inflammatory response, including a white blood cell count of $4000 / \mu \mathrm{L}$ with $90 \%$ segmented neutrophils and no band neutrophils and C-reactive protein level elevation to $8.8 \mathrm{mg} / \mathrm{dL}$. The red blood cell count, hemoglobin level, and hematocrit value were $466 \times 10^{4} / \mathrm{mL}, 13.4 \mathrm{~g} / \mathrm{dL}$, and $33.0 \%$, respectively. Cerebrospinal fluid analysis revealed a slight increase in cell count; the total cell count, mononuclear cell count, and polynuclear cell count were $91 / \mathrm{mL}$, $6 / \mathrm{mL}$, and $85 / \mathrm{mL}$, respectively. The protein, glucose, and chloride levels in cerebrospinal fluid were $54 \mathrm{mg} / \mathrm{dL}$, $52 \mathrm{mg} / \mathrm{dL}$, and $117 \mathrm{mEq} / \mathrm{L}$, respectively. Thoracoabdominal CT revealed no fever-causing lesions. Head CT revealed no intracranial space-occupying lesions or vascular abnormalities. She was admitted to our hospital for conservative treatment of suspected meningitis. Her high fever persisted; therefore, IV antibiotics were administered on the day of admission. She had painless erythematous nodules on her limbs. On day 2 of admission, she developed impaired consciousness (Glasgow Coma Scale score: 9 [eye opening: 2, best verbal response: 2 , and best motor response: 5]), acute left hemiparesis, left hemispatial neglect, and dysarthria (National Institutes of Health Stroke Scale [NIHSS] score: 16). MRA showed occlusion of the right M1 segment of the middle cerebral artery (MCA). Diffusion-weighted imaging showed hyperintense signals in the right basal ganglia and temporal cortex (Fig. 1A and 1B).

She was diagnosed with disseminated intravascular coagulation (DIC) based on the high inflammatory response, fibrin degradation product level $(33 \mu \mathrm{g} / \mathrm{mL})$, and prothrombin time-international normalized ratio (1.5) as well as the low platelet count $\left(3.1 \times 10^{4} / \mu \mathrm{L}\right)$ and fibrinogen level $(155 \mathrm{mg} / \mathrm{dL})$. rtPA therapy was not administered because of the decreased platelet levels. She immediately underwent MT. Under local anesthesia, a 9-Fr introducer sheath was placed in the right femoral artery and a 9-Fr balloon guide catheter (Optimo; Tokai Medical Products, Aichi, Japan) was placed in the right internal carotid artery. Initial angiography revealed persistent occlusion of proximal M1 segment of the MCA (Fig. 1C). MT was performed after heparinization (5000 units of heparin; activated clotting time: $308 \mathrm{~s}$ ). The occlusion was crossed without friction and difficulty with a micro guidewire (Traxcess 12-14 200; Terumo, Aliso Viejo, CA, USA) and microcatheter (Marksman; Medtronic, Irvine, CA, USA) using a Penumbra 5MAX ACE (Penumbra, Alameda, CA, USA) as a distal access catheter. The stentretrieving into an aspiration catheter with proximal balloon (ASAP) technique was performed using the Trevo XP ProVue $4 \times 20 \mathrm{~mm}$ stent retriever (SR) (Stryker, Kalamazoo, MI, USA). ${ }^{6)}$ To minimize arterial wall damage due to traction from the SR, the 5MAX ACE was guided to the distal end of the M1 segment of the MCA with continuous suction. After a single pass, we achieved a successful reperfusion (thrombolysis in cerebral infarction [TICI] 2b) with no procedural complications. Only the M3 opercular branch of the MCA remained occluded (Fig. 1D). Parts of the retrieved clot were white and vitreous; it was sent for pathological examination. There was no intraoperative arterial vasospasm. Hemostasis at the inguinal puncture site was achieved using an Angio-Seal vascular closure device (St. Jude Medical, St. Paul, MN, USA).

Postoperatively, she improved clinically; her NIHSS score was 12, and she could lift her left upper and lower limbs against gravity, indicating an improvement in her hemiparesis. MRI performed on the first postoperative day revealed right basal ganglia infarction and no hemorrhage (Fig. 1E and 1F).

The results of the pathological examination of the retrieved clot are as follows. Gram staining revealed a bacterial mass composed of Gram-positive cocci surrounded by infiltration of inflammatory cells. Subsequently, Staphylococcus aureus was detected on blood culture (Fig. 1G), and transthoracic echocardiography revealed moderate mitral regurgitation and a mitral valve vegetation. Transesophageal echocardiography revealed a mobile vegetation on the anterior cusp of the mitral valve and anterior mitral valve perforation, confirming the diagnosis of IE. Mitral valve replacement was performed at another hospital 2 days after thrombectomy. Subsequently, antibiotic therapy was continued for 6 weeks, and the patient underwent rehabilitation. Whole-body CT was performed multiple times during the course, but no clear cause of IE was identified. After rehabilitation, her left hemiparesis recovered almost completely (slight impairment of finger dexterity remained). The modified Rankin Scale (mRS) score after 90 days was 1 .

\section{Discussion}

Ischemic stroke has a devastating impact on adults younger than 45 years, given their extended duration of disability, 


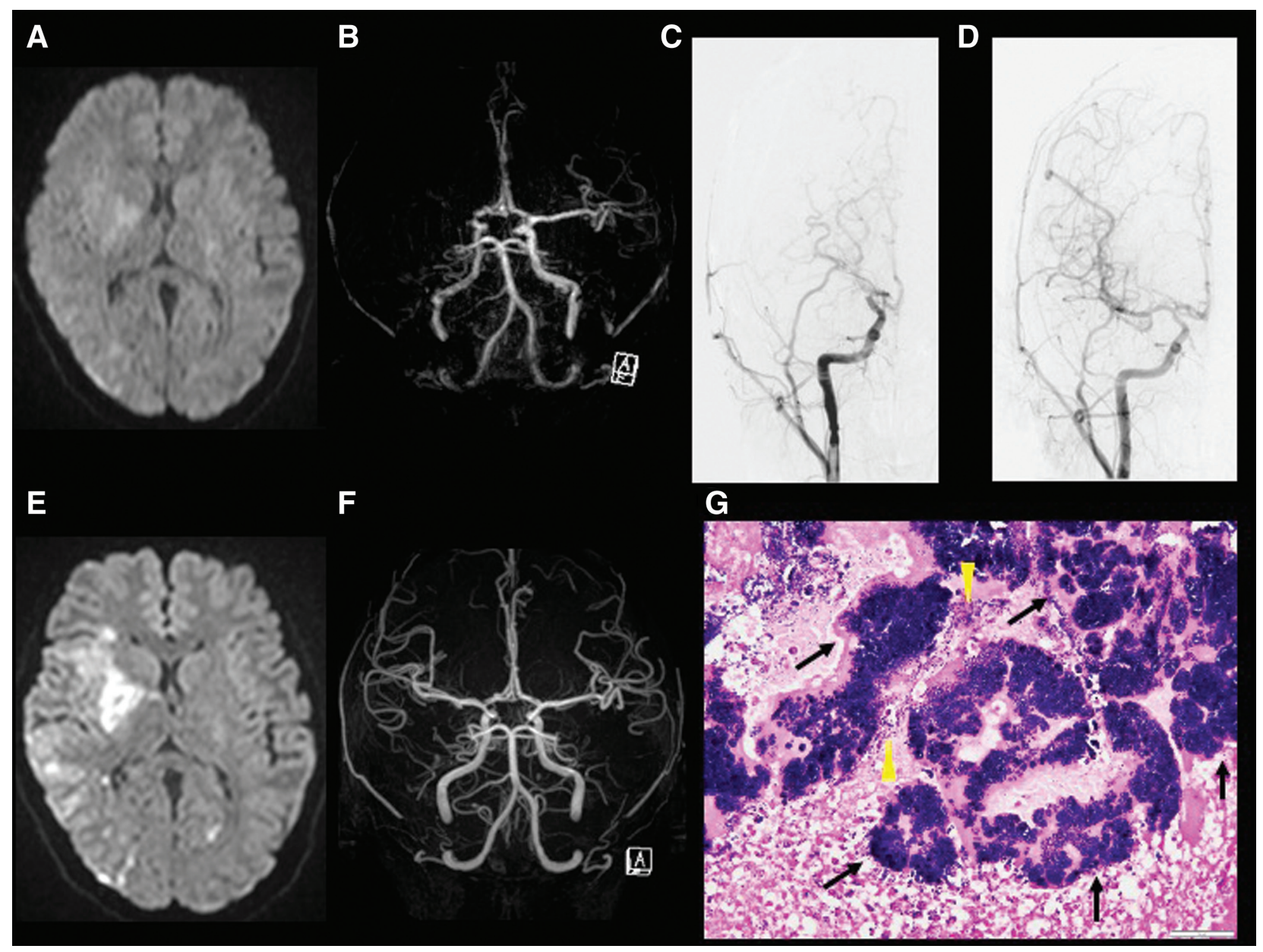

Fig. 1 (A) Diffusion-weighted MRI shows slightly hyperintense regions in the right basal ganglia and temporal cortex. (B) MRA image shows occlusion of the right M1 segment of the MCA. (C) Internal cerebral angiography image shows occlusion of the right M1 segment of the MCA. (D) After a single pass with a Trevo SR and Penumbra catheter, we achieved MCA recanalization ( $\mathrm{TICl} 2 \mathrm{~b}$ ). (E) Diffusion-weighted image obtained on the first postoperative day

frequent caregiver requirement, and continued exposure to complications. ${ }^{7)}$ McCarty et al. found that young adults (18-45 years) have ischemic strokes secondary to cardioembolism more often than older adults; they are categorized based on sterility, cardiac disease, or clot composition, which includes septic, bland, air, and fat emboli. ${ }^{1)} \mathrm{IE}$ is an important cause of cerebral infarction in young adults; it has a severe prognosis, and less than one-third of the patients survive and remain functionally independent. The prognosis of IE is poor when acute LVO leads to cerebral infarction. ${ }^{2)}$

To date, only one cohort study and one case-control study (12 and 55 patients, respectively) have examined patients with IE-related acute LVO who underwent MT, ${ }^{8,9)}$ and they reported the incidence of IE-induced emboli as shows left basal ganglia and temporal cortex infarction. (F) MRA image shows recanalization of the M1 segment of the right MCA. (G) Pathological findings (original magnification $\times 100$ ). A bacterial mass composed of Gram-positive cocci (black arrows) surrounded by infiltration of inflammatory cells (yellow arrowheads) is seen on Gram staining. MCA: middle cerebral artery; SR: stent retriever; TICI: thrombolysis in cerebral infarction

$0.8 \%$ and $1.4 \%$, respectively. Ramos et al. and Feil et al. reported that stroke due to IE-induced septic emboli was associated with poorer overall clinical outcomes than cardioembolic stroke. ${ }^{8,9)}$ Feil et al. suggested that this may be due to low recanalization rates and delays in performing thrombectomy, $\left.{ }^{9}\right)$ whereas Ramos et al. suggested that it may be due to low recanalization rates, hemorrhagic complications, cardiovascular comorbidities, or systemic conditions associated with severe infection. ${ }^{8}$

Our literature review on the predisposing factors, baseline symptoms, presence of heart murmur, inflammatory marker levels on blood tests, pathogens isolated on blood culture, timing of stroke, NIHSS score at stroke onset, site of LVO, treatment, TICI grade, clot color, examination performed on the clot, presence of symptomatic 
Table 1 Characteristics of young patients (<45 years) with stroke and IE with MT. Baseline demographic characteristics of patients and IE features

\begin{tabular}{|c|c|c|c|c|c|c|c|c|}
\hline Case & Author & $\begin{array}{l}\text { Age/ } \\
\text { sex }\end{array}$ & $\begin{array}{l}\text { Predispos- } \\
\text { ing factor }\end{array}$ & $\begin{array}{l}\text { Baseline } \\
\text { symptoms }\end{array}$ & $\begin{array}{l}\text { Heart } \\
\text { murmur }\end{array}$ & $\begin{array}{l}\text { Inflammatory } \\
\text { markers }\end{array}$ & $\begin{array}{l}\text { Blood culture } \\
\text { pathogen }\end{array}$ & $\begin{array}{l}\text { Timing of } \\
\text { stroke }\end{array}$ \\
\hline 1 & $\begin{array}{l}\text { Bain } \\
(2011)^{10}\end{array}$ & $24 / F$ & $\begin{array}{l}\text { LVAD } \\
\text { placement }\end{array}$ & NR & NR & NR & Gram-positive bacilli & $\begin{array}{c}\text { After IE } \\
\text { diagnosis }\end{array}$ \\
\hline 2 & $\begin{array}{l}\text { Sukumaran } \\
(2012)^{11}\end{array}$ & $33 / \mathrm{NR}$ & $\begin{array}{l}\text { Mitral } \\
\text { stenosis }\end{array}$ & $\begin{array}{l}\text { Fever and } \\
\text { malaise }\end{array}$ & $\begin{array}{l}\text { Aortic } \\
\text { murmur }\end{array}$ & $\begin{array}{l}\text { CRP } 10.1 \\
\mathrm{mg} / \mathrm{dL}\end{array}$ & Gram-positive bacilli & $\begin{array}{c}\text { After IE } \\
\text { diagnosis }\end{array}$ \\
\hline 3 & $\begin{array}{l}\text { Kang } \\
(2013)^{12}\end{array}$ & $39 / F$ & $\begin{array}{l}\text { Cardio- } \\
\text { vascular } \\
\text { disorder }\end{array}$ & $\begin{array}{l}\text { Fever for a } \\
\text { month }\end{array}$ & NR & $\begin{array}{l}\text { WBC } \\
8600 / \mu \mathrm{L}\end{array}$ & $\begin{array}{l}\text { Streptococcus } \\
\text { gordonii }\end{array}$ & $\begin{array}{l}\text { Before IE } \\
\text { diagnosis }\end{array}$ \\
\hline 4 & $\begin{array}{l}\text { Kim JM } \\
(2014)^{13}\end{array}$ & $40 / F$ & - & $\begin{array}{l}\text { Fever and } \\
\text { malaise }\end{array}$ & $\begin{array}{l}\text { Aortic } \\
\text { murmur }\end{array}$ & $\begin{array}{c}\text { WBC } \\
15410 / \mu \mathrm{L}\end{array}$ & Streptococcus mitis & $\begin{array}{l}\text { Before IE } \\
\text { diagnosis }\end{array}$ \\
\hline 5 & $\begin{array}{l}\text { Ladner } \\
(2015)^{14}\end{array}$ & $40 / \mathrm{NR}$ & $\begin{array}{l}\text { IV opiate } \\
\text { use }\end{array}$ & $\begin{array}{c}\text { Severe } \\
\text { dyspnea }\end{array}$ & NR & NR & Enterococcus faecalis & $\begin{array}{c}\text { After IE } \\
\text { diagnosis }\end{array}$ \\
\hline 6 & $\begin{array}{l}\text { Sveinsson } \\
(2016)^{15}\end{array}$ & $33 / \mathrm{M}$ & $\begin{array}{l}\text { Prosthetic } \\
\text { mitral } \\
\text { valve }\end{array}$ & $\begin{array}{l}\text { High-grade } \\
\text { fever }\end{array}$ & NR & NR & Serratia marcescens & $\begin{array}{l}\text { After IE } \\
\text { diagnosis }\end{array}$ \\
\hline 7 & & $39 / F$ & $\begin{array}{l}\text { Anorexia } \\
\text { nervosa }\end{array}$ & NR & NR & NR & NR & $\begin{array}{l}\text { Before IE } \\
\text { diagnosis }\end{array}$ \\
\hline 8 & $\begin{array}{l}\text { Bolognese } \\
(2018)^{16}\end{array}$ & $42 / \mathrm{M}$ & - & Fever & $\begin{array}{l}\text { Aortic } \\
\text { murmur }\end{array}$ & $\begin{array}{c}\text { WBC } \\
11200 / \mu \mathrm{L}\end{array}$ & $\begin{array}{l}\text { Streptococcus } \\
\text { viridans }\end{array}$ & $\begin{array}{l}\text { Before IE } \\
\text { diagnosis }\end{array}$ \\
\hline 9 & $\begin{array}{l}\text { Cuervo } \\
(2018)^{17}\end{array}$ & $42 / \mathrm{M}$ & NR & NR & NR & NR & $\begin{array}{l}\text { Streptococcus } \\
\text { mutans }\end{array}$ & $\begin{array}{l}\text { Before IE } \\
\text { diagnosis }\end{array}$ \\
\hline 10 & & $43 / \mathrm{M}$ & NR & NR & NR & NR & Enterococcus faecalis & $\begin{array}{l}\text { Before IE } \\
\text { diagnosis }\end{array}$ \\
\hline 11 & & $34 / \mathrm{M}$ & NR & NR & NR & NR & $\begin{array}{l}\text { Granulicatella adia- } \\
\text { cens }\end{array}$ & $\begin{array}{l}\text { Before IE } \\
\text { diagnosis }\end{array}$ \\
\hline 12 & $\begin{array}{l}\text { Sgreccia } \\
(2020)^{18}\end{array}$ & $31 / \mathrm{M}$ & $\begin{array}{l}\text { Azathio- } \\
\text { prine use }\end{array}$ & Fever & $\begin{array}{l}\text { Aortic } \\
\text { murmur }\end{array}$ & $\begin{array}{l}\text { CRP } 5.22 \\
\mathrm{mg} / \mathrm{dL}\end{array}$ & Candida parapsilosis & $\begin{array}{l}\text { Before IE } \\
\text { diagnosis }\end{array}$ \\
\hline 13 & $\begin{array}{l}\text { D'Anna } \\
(2020)^{2}\end{array}$ & $30 / F$ & - & $\begin{array}{l}\text { Sore throat, } \\
\text { lethargy, } \\
\text { and general } \\
\text { malaise }\end{array}$ & NR & $\begin{array}{l}\text { CRP } 14.5 \\
\mathrm{mg} / \mathrm{dL}\end{array}$ & $\begin{array}{c}\text { Neisseria gonor- } \\
\text { rhoeae }\end{array}$ & $\begin{array}{l}\text { Before IE } \\
\text { diagnosis }\end{array}$ \\
\hline 14 & $\begin{array}{l}\text { Ramos } \\
(2020)^{8}\end{array}$ & $32 / \mathrm{M}$ & NR & NR & NR & NR & $\begin{array}{l}\text { Staphylococcus } \\
\text { epidermidis }\end{array}$ & NR \\
\hline 15 & $\begin{array}{l}\text { Present } \\
\text { case }\end{array}$ & $18 / F$ & - & $\begin{array}{l}\text { Fever, rush } \\
\text { of limbs }\end{array}$ & NR & $\begin{array}{c}\text { WBC } \\
15200 / \mu \mathrm{L}\end{array}$ & $\begin{array}{c}\text { Staphylococcus } \\
\text { aureus }\end{array}$ & $\begin{array}{l}\text { Before IE } \\
\text { diagnosis }\end{array}$ \\
\hline
\end{tabular}

CRP: C-reactive protein; F: female; IE: infective endocarditis; IV: intravenous; LVAD: left ventricular assist device; M: male; MT: mechanical thrombectomy; NR: not reported; WBC: white blood cell

intracerebral hemorrhage ( $\mathrm{ICH})$, and outcome of MT in young patients $(<45$ years) with IE-induced LVO revealed 11 reports describing 15 cases of MT (Tables 1 and 2). 2,6,10-18) The mean age of all 15 patients (14 patients from previous reports and our patient) was 34.7 years (range: 18-43 years). Ours was the youngest reported patient to undergo MT for IE-related acute LVO. Ten of the patients had been diagnosed with IE after stroke; seven had a history of IE risk factors, such as heart disease or immunodeficiency; seven had fever for several days; four had a heart murmur; and seven had inflammatory marker elevation. This indicates that not all young patients with IEinduced LVO have a predisposing disease and develop fever. Therefore, systemic diagnosis based on findings of heart murmur and an increased inflammatory response is important. Our patient had painless erythematous nodules on her limbs, which were considered to be Janeway lesions characteristic of IE, and this was useful for diagnosis. ${ }^{19}$

In six cases, including this one, the color of the thrombus has been described or a photograph of the thrombus has been included. A white thrombus with a vitreous part was reported in five of them, including this case. Scharf et al. reported that unlike normal white and red thrombi, the emboli of patients with IE contain bacteria and inflammatory cells in addition to platelets and fibrin, which results in a vitreous appearance. ${ }^{20)}$ Pathological examination of the retrieved thrombus was performed in six cases, including this one. Nakanishi et al. reported that pathological 
Table 2 Characteristics of young patients (<45 years) with stroke and IE with MT. Baseline clinical and imaging characteristics of patients, treatment details, clinical evolution after thrombectomy, and safety outcomes

\begin{tabular}{|c|c|c|c|c|c|c|c|c|c|c|}
\hline Case & Author & $\begin{array}{l}\text { Onset } \\
\text { NIHSS }\end{array}$ & $\begin{array}{l}\text { LVO } \\
\text { site }\end{array}$ & $\begin{array}{l}\text { Treat- } \\
\text { ment } \\
\text { with IV } \\
\text { throm- } \\
\text { bolysis }\end{array}$ & $\begin{array}{l}\text { Endo- } \\
\text { vascular } \\
\text { revascu- } \\
\text { larization } \\
\text { technique }\end{array}$ & $\mathrm{TICl}$ & $\begin{array}{l}\text { Type of } \\
\text { analysis on } \\
\text { the clot }\end{array}$ & $\mathrm{ICH}$ & $\begin{array}{c}\text { NIHSS } \\
\text { outcome }\end{array}$ & $\begin{array}{l}\mathrm{mRS} \text { at } \\
\text { follow-up }\end{array}$ \\
\hline 1 & Bain et al. ${ }^{10)}$ & 18 & ICA & No & SR & $\begin{array}{c}\text { NR } \\
\text { (reca- } \\
\text { nalised) }\end{array}$ & $\begin{array}{c}\text { Blood } \\
\text { cultures- } \\
\text { Gram's stain }\end{array}$ & No & $\begin{array}{c}7 \text { at } 24 \\
\text { hours; } 2 \text { at } \\
60 \text { days }\end{array}$ & NR \\
\hline 2 & $\begin{array}{l}\text { Sukumaran } \\
\text { et al. }{ }^{11)}\end{array}$ & 14 & M1 & No & SR & $\begin{array}{c}\text { NR } \\
\text { (reca- } \\
\text { nalised) }\end{array}$ & $\begin{array}{c}\text { Blood } \\
\text { cultures- } \\
\text { Gram's stain }\end{array}$ & No & $\begin{array}{c}4 \text { at } 24 \\
\text { hours; } 0 \text { at } \\
4 \text { days }\end{array}$ & NR \\
\hline 3 & $\begin{array}{l}\text { Kang } \\
\text { et al. }{ }^{12)}\end{array}$ & 16 & M1 & No & SR & $2 b$ & No & No & $\begin{array}{c}3 \text { at } 28 \\
\text { days }\end{array}$ & NR \\
\hline 4 & Kim et al. ${ }^{13)}$ & 15 & M1 & No & Aspiration & $\begin{array}{c}\text { NR } \\
\text { (reca- } \\
\text { nalised) }\end{array}$ & $\begin{array}{c}\text { Blood } \\
\text { cultures- } \\
\text { Gram's stain }\end{array}$ & No & $\begin{array}{c}3 \text { at } 2 \\
\text { days }\end{array}$ & $\begin{array}{c}2 \text { at } 90 \\
\text { days }\end{array}$ \\
\hline 5 & $\begin{array}{l}\text { Ladner } \\
\text { et al. }{ }^{14)}\end{array}$ & 3 & M1 & No & Aspiration & 3 & No & No & $\begin{array}{c}0 \text { at } 13 \\
\text { days }\end{array}$ & $\begin{array}{c}0 \text { at } 13 \\
\text { days }\end{array}$ \\
\hline 6 & $\begin{array}{l}\text { Sveinsson } \\
\text { et al. }{ }^{15)}\end{array}$ & 14 & M1 & No & SR & $\begin{array}{c}\text { NR } \\
\text { (reca- } \\
\text { nalised) }\end{array}$ & No & No & $\begin{array}{c}1 \text { at } \\
\text { discharge }\end{array}$ & $\begin{array}{l}1 \text { at dis- } \\
\text { charge }\end{array}$ \\
\hline 7 & & 15 & M2 & No & SR & $\begin{array}{c}\text { NR } \\
\text { (reca- } \\
\text { nalised) }\end{array}$ & No & No & $\begin{array}{c}3 \text { at } \\
\text { discharge }\end{array}$ & $\begin{array}{c}2 \text { at } 90 \\
\text { days }\end{array}$ \\
\hline 8 & $\begin{array}{l}\text { Bolognese } \\
\text { et al. }{ }^{16)}\end{array}$ & 3 & M2 & No & Aspiration & $2 b$ & $\begin{array}{l}\text { Blood } \\
\text { cultures }\end{array}$ & No & $\begin{array}{c}0 \text { at } 28 \\
\text { days }\end{array}$ & NR \\
\hline 9 & $\begin{array}{l}\text { Cuervo } \\
\text { et al. }{ }^{17)}\end{array}$ & 5 & M2 & NR & NR & NR & No & No & $\begin{array}{c}1 \text { at } \\
\text { discharge }\end{array}$ & NR \\
\hline 10 & & 22 & M1 & NR & NR & NR & No & No & $\begin{array}{c}12 \text { at } \\
\text { discharge }\end{array}$ & NR \\
\hline 11 & & 24 & M1 & NR & NR & NR & No & No & $\begin{array}{c}6 \text { at } \\
\text { discharge }\end{array}$ & NR \\
\hline 12 & $\begin{array}{l}\text { Sgreccia } \\
\text { et al. }{ }^{18)}\end{array}$ & 18 & M1 & Yes & SR & 3 & $\begin{array}{c}\text { White- } \\
\text { colored } \\
\text { aspect } \\
\text { PCR analysis }\end{array}$ & No & $\begin{array}{c}0 \text { at } \\
2 \text { days }\end{array}$ & $\begin{array}{c}0 \text { at } 90 \\
\text { days }\end{array}$ \\
\hline 13 & D’Anna²) & 22 & M2 & No & $\begin{array}{l}\text { Aspiration } \\
\text { and SR }\end{array}$ & $2 a$ & No & Yes & $\begin{array}{c}22 \text { at } \\
24 \text { hours }\end{array}$ & $\begin{array}{c}3 \text { at } 90 \\
\text { days }\end{array}$ \\
\hline 14 & $\begin{array}{l}\text { Ramos } \\
(2020)^{8}\end{array}$ & 18 & ICA & No & NR & 0 & No & No & $\begin{array}{c}26 \text { at } \\
24 \text { hours }\end{array}$ & $\begin{array}{l}2 \text { at } 90 \\
\text { days }\end{array}$ \\
\hline 15 & $\begin{array}{c}\text { Present } \\
\text { case }\end{array}$ & 16 & M1 & No & $\begin{array}{l}\text { Aspiration } \\
\text { and SR }\end{array}$ & $2 b$ & $\begin{array}{c}\text { Blood } \\
\text { cultures- } \\
\text { Gram's stain }\end{array}$ & No & $\begin{array}{c}12 \text { at } \\
12 \text { hours }\end{array}$ & $\begin{array}{c}1 \text { at } 60 \\
\text { days }\end{array}$ \\
\hline
\end{tabular}

ICA: internal carotid artery; ICH: intracerebral hemorrhage; IE: infective endocarditis; IV: intravenous; LVO: large vessel occlusion; mRS: modified Ranking Scale; M1: horizontal segment of middle cerebral artery; M2: insular segment of middle cerebral artery; MT: mechanical thrombectomy; NIHSS: National Institutes of Health Stroke Scale; NR: not reported; SR: stent retriever; TICl: thrombolysis in cerebral infarction

examination of the thrombus is useful for diagnosing IE in patients undergoing MT.21)

In the previously reported cases, only one patient received both MT and IV thrombolysis. Our patient was not administered IV thrombolysis due to her low platelet count, and IE was suspected based on symptoms and blood examination findings. Bettencourt et al. found that patients with IE-related acute ischemic stroke were more likely to experience intracerebral hemorrhage when treated with IV thrombolysis or combined treatment than patients treated with thrombectomy alone. ${ }^{22)}$ Moreover, MT was performed using an SR alone in six cases, using an aspiration catheter alone in three cases, and using a combined technique in two cases. There was a high risk of hemorrhage in our patient as she had DIC and decreased platelet counts. Therefore, we performed the ASAP 
technique, which has been reported to have few hemorrhagic complications. $\left.{ }^{6}\right)$ In addition, to minimize friction between the vascular intima and the SR, the aspiration catheter was advanced further than where it is usually placed in the ASAP technique to overlap the SR. Gurkas et al. reported that ADVANCE technique, in which the aspiration catheter is advanced further than the SR, results in a higher rate of revascularization with no emboli to new territory and no hemorrhagic complication and fewer distal emboli to target territory than MT with SR in patients with LVO. ${ }^{23}$

Our literature review revealed that the TICI grade was $2 b$ or higher in five of the seven cases described. Symptomatic ICH occurred in only one patient. The long-term prognosis of one patient was unknown. Nevertheless, based on the NIHSS and mRS scores reported, we believe that 11 of the remaining 14 patients achieved functional independence. Although the possibility of publication bias should be considered, a good prognosis is expected in young patients with IE-induced cerebral infarction through aggressive treatment and investigation of the cause.

\section{Conclusion}

We report the case of the youngest acute LVO patient to date to be diagnosed with IE-induced septic emboli. Rapid diagnosis and MT should be performed in young patients with IE-induced LVO.

\section{Disclosure Statement}

The authors declare no conflicts of interest.

\section{References}

1) McCarty JL, Leung LY, Peterson RB, et al. Ischemic infarction in young adults: a review for radiologists. Radiographics 2019; 39: 1629-1648.

2) D’Anna L. Endovascular treatment of ischemic largevessel stroke due to infective endocarditis: case series and review of the literature. Neurol Sci 2020; 41: 3517-3525.

3) Sloane KL, Raymond SB, Rabinov JD, et al. Mechanical thrombectomy in stroke from infective endocarditis: case report and review. J Stroke Cerebrovasc Dis 2000; 29: 104501 .

4) Li JS, Sexton DJ, Mick N, et al. Proposed modifications to the Duke criteria for the diagnosis of infective endocarditis. Clin Infect Dis 2000; 30: 633-638.
5) Asaithambi G, Adil MM, Qureshi AI. Thrombolysis for ischemic stroke associated with infective endocarditis: results from the nationwide inpatient sample. Stroke 2013; 44: 2917-2919.

6) Goto S, Ohshima T, Ishikawa K, et al. A stent-retrieving into an aspiration catheter with proximal balloon (ASAP) technique: a technique of mechanical thrombectomy. World Neurosurg 2018; 109: e468-e475.

7) Benjamin EJ, Virani SS, Callaway CW, et al. Heart disease and stroke statistics: 2018 update - a report from the American Heart Association. Circulation 2018; 137: e67-e492.

8) Ramos C, Mayo P, Trillo S, et al. Management of large vessel occlusion stroke related to infective endocarditis: is mechanical thrombectomy a safe option? J Stroke Cerebrovasc Dis 2020; 29: 105248.

9) Feil K, Küpper C, Tiedt S, et al. Safety and efficacy of mechanical thrombectomy in infective endocarditis: a matched case-control analysis from the German Stroke RegistryEndovascular Treatment. Eur J Neurol 2021; 28: 861-867.

10) Bain MD, Hussain MS, Gonugunta V, et al. Successful recanalization of a septic embolus with a balloon mounted stent after failed mechanical thrombectomy. J Neuroimaging 2011; 21: 170-172.

11) Sukumaran S, Jayadevan ER, Mandilya A, et al. Successful mechanical thrombectomy of acute middle cerebral artery occlusion due to vegetation from infective endocarditis. Neurol India 2012; 60: 239-240.

12) Kang G, Yang TK, Choi JH, et al. Effectiveness of mechanical embolectomy for septic embolus in the cerebral artery complicated with infective endocarditis. J Korean Med Sci 2013; 28: 1244-1247.

13) Kim JM, Jeon JS, Kim YW, et al. Forced arterial suction thrombectomy of septic embolic middle cerebral artery occlusion due to infective endocarditis: an illustrative case and review of the literature. Neurointervention 2014; 9: 101-105.

14) Ladner TR, Davis BJ, He L, et al. Complex decisionmaking in stroke: preoperative mechanical thrombectomy of septic embolus for emergency cardiac valve surgery. J Neurointerv Surg 2015; 7: e41.

15) Sveinsson O, Herrman L, Holmin S. Intra-arterial mechanical thrombectomy: an effective treatment for ischemic stroke caused by endocarditis. Case Rep Neurol 2016; 8: 229-233.

16) Bolognese M, von Hessling A, Müller M. Successful thrombectomy in endocarditis-related stroke: case report and review of the literature. Interv Neuroradiol 2018; 24: 529-532.

17) Cuervo G, Caballero Q, Rombauts A, et al. Mechanical thrombectomy for patients with infective endocarditis and ischemic large-vessel stroke. Clin Infect Dis 2018; 67: 1145-1146.

18) Sgreccia $A$, Carità $G$, Coskun $O$, et al. Acute ischemic stroke treated with mechanical thrombectomy and fungal 
endocarditis: a case report and systematic review of the literature. J Neuroradiol 2020; 47: 386-392.

19) Panginikkod S, Gopalakrishnan V, Parikh M, et al. Janeway lesions: a painless manifestation of infective endocarditis. $J$ Gen Intern Med 2019; 34: 1360-1361.

20) Scharf EL, Chakraborty T, Rabinstein A, et al. Endovascular management of cerebral septic embolism: three recent cases and review of the literature. J Neurointerv Surg 2017; 9: 463-465.
21) Nakanishi K, Kawano H, Amano T, et al. [Stroke due to infective endocarditis diagnosed by the retrieved thrombus: a case report]. Rinsho Shinkeigaku 2018; 58: 35-40. (in Japanese)

22) Bettencourt S, Ferro JM. Acute ischemic stroke treatment in infective endocarditis: systematic review. J Stroke Cerebrovasc Dis 2020; 29: 104598.

23) Gurkas E, Akpinar CK, Aytac E. ADVANCE: an effective and feasible technique in acute stroke treatment. Interv Neuroradiol 2017; 23: 166-172. 